CZASOPISMO INŻYNIERII LACDOWEJ, ŚRODOWISKA I ARCHITEKTURY JOURNAL OF CIVIL ENGINEERING, ENVIRONMENT AND ARCHITECTURE

JCEEA, t. XXXII, z. 62 (3/I/15), lipiec-wrzesień 2015, s. 497-510

\author{
Lukasz WESOŁOWSKI ${ }^{1}$
}

\title{
WPLYW PRZESZKLONYCH ŚCIAN OSŁONOWYCH NA KOMFORT ŚRODOWISKA W POMIESZCZENIACH MIESZKALNYCH - WYBRANE ASPEKTY
}

\begin{abstract}
Stosowanie przeszklonych ścian osłonowych w budynkach mieszkalnych jest coraz częściej spotykaną praktyką. Rozwiązania te posiadają wiele zalet - zwłaszcza estetycznych - jednak przy nieodpowiednim stosowaniu powodują powstanie wielu problemów natury użytkowej i bardzo silnie wpływają na jakość środowiska wewnętrznego. Wymieniono i omówiono wybrane aspekty stosowania dużych przeszkleń pod kątem wpływu na komfort wewnątrz pomieszczeń mieszkalnych. Stosowano analogie i porównania do rozpoznanych zjawisk występujących w innych typach budynków i przeanalizowano je uwzględniając specyfikę budownictwa mieszkaniowego. Praca podejmuje próbę określenia elementów składowych komfortu środowiska wewnętrznego pomieszczeń mieszkalnych, prezentując go w ujęciu mierzalnym i niemierzalnym. W analizie rozwiązań uwzględniono wpływ czynników psychologicznych i fizycznych oraz poruszono problematykę kontekstu społecznego. Spośród aspektów stosowania ścian osłonowych praca omawia zagadnienia związane $\mathrm{z}$ bezpieczeństwem pożarowym, kwestiami energetycznymi oraz przeziernością przegród szklanych. Artykuł opisuje technologię budowlaną oraz specyficzne rozwiązania techniczne pozwalające na wykorzystanie zalet dużych powierzchni przeszkleń oraz zapewniających ograniczenie niepożądanego wpływu na jakość środowiska wewnętrznego. Pośrednim celem pracy jest również zwrócenie uwagi na konieczność szerokiego spojrzenia na problematykę stosowania tego typu przegród, zwłaszcza w budynkach mieszkalnych. Złożoność uwarunkowań i szeroki zakres wzajemnych interakcji zwiększają stopień złożoności dokumentacji technicznej wymuszając wielobranżowe konsultacji już we wczesnej fazie prac projektowych. Autor podejmuje próbę skatalogowania rozwiązań i określenia pól przydatności ich stosowania w oparciu o przyjęte wytyczne projektowe.
\end{abstract}

Słowa kluczowe: bezpieczeństwo pożarowe przeszkleń, akumulacyjność cieplna, prywatność przy przeszkleniach, zyski i straty ciepła przez przeszklenia

\section{Wprowadzenie}

Obserwuje się dążenie do projektowania budynków mieszkalnych $\mathrm{z}$ wykorzystaniem przeszkleń o znacznej powierzchni. Trend od dawna widocz-

\footnotetext{
${ }^{1}$ Łukasz Wesołowski, Politechnika Krakowska, 31-155 Kraków, ul. Warszawska 24, tel. 501023567, lukaszw@pk.edu.pl
} 
ny w transparentnych formach biurowców i budynków handlowych jest kojarzony z prestiżem, indywidualnością i elegancją. Nietuzinkowa estetyka tego typu przegród powoduje, że technologia zaczerpnięta z budynków użyteczności publicznej coraz częściej pojawia się w realizacjach domów i apartamentowców. Przeszklone ściany osłonowe podlegają ciągłej ewolucji. Stosowane od dziesięcioleci rozwinęły się w kilka typów konstrukcyjnych i obecnie są pełnowartościową przegrodą zewnętrzną. Znakomicie odpowiadały na zapotrzebowanie funkcji komercyjnych i produkcyjnych realizując przyjęty tam model komfortu wewnętrznego, prywatności i termiki. Czy jednak adaptacja tego typu rozwiązań na gruncie funkcji mieszkalnych zapewni sprostanie nowy wymaganiom? Czy sprawdza się przeniesienie sprawdzonych, gotowych rozwiązań do obiektów z kręgu architektury mieszkaniowej? Problematykę wybranych aspektów projektowania przeszklonych ścian osłonowych w budynkach mieszkalnych omawia się pod kątem jakości środowiska wewnętrznego.

Ściany osłonowe są zaliczane do przegród, które nie pełnią roli konstrukcyjnej, czyli nie przenoszą obciążeń pochodzących ze stropów. Stosuje się je jako wypełnienia otworów oraz jako stałe wymknięcia części budynków. Rozwiązania techniczne zapewniają całkowitą izolację wnętrz od czynników zewnętrznych. Decyzje projektowe co do stosowania przeszklonych odmian ścian osłonowych powinny wynikać z analiz środowiskowych przeprowadzanych dla konkretnych obiektów i lokalizacji. Wielowątkowe symulację powinny mieć na celu chęć osiągnięcia jak najlepszych warunków do przebywania ludzi. Jeżeli zatem wybór dużych przeszkleń podyktowany jest pobudkami estetycznymi, należy prześledzić implikacje ich stosowania pod kątem termiki, oświetlenia naturalnego, akustyki, jakości powietrza wewnętrznego i wielu innych czynników. Szczególnie problematyczna ze względu na umiejscawianie przeszkleń może być wielkoprzestrzena multiplikacja zysków energetycznych, powierzchniowe skraplanie się pary wodnej, czy problem z zachowaniem prywatności w projektowanych wnętrzach. Koniecznym do wspomnienia jest aspekt estetyczno użytkowy utrzymania przegrody w czystości. Transparentny charakter ściany osłonowej wymaga częstego czyszczenia powierzchni (zwłaszcza wewnętrznych) narażonych na bezpośredni kontakt z użytkownikami.

\section{Komfort pomieszczeń mieszkalnych}

$\mathrm{Na}$ odczuwalny komfort użytkowania pomieszczeń mają wpływ parametry subiektywne i obiektywne. Możemy zmierzyć parametry opisujące szereg własności takich jak temperatura, ciśnienie i wilgotność powietrza, temperaturę poszczególnych przegród i energię $\mathrm{z}$ nich wypromieniowywaną, natężenie oświetlenia naturalnego, procentowy udział przejrzystości przegrody pod względem elementów składowych i wiele innych. Na odczuwalny poziom komfortu mają wpływ czynniki fizyczne w połączeniu $\mathrm{z}$ wrażeniami wizualnymi, odbieranymi razem behawioralne. Obojętność wobec wszystkich czynników 
(brak odczuwania niekorzystnych warunków) najczęściej postrzegana jest jako komfort otoczenia. Odbierana jest podświadomie jako przestrzeń, w której możemy się skutecznie skupić lub odprężyć. W pomieszczeniach mieszkalnych zmieniają się również proporcje składników jakościowych. Porównując je $\mathrm{z}$ budynkami komercyjnymi oczekujemy od mieszkań wyższego poziomu prywatności, wyższego poziomu ciszy, mamy również niższą tolerancję dla odchyleń od tych wartości. Wyższe oczekiwania nawiązują do zmiany podmiotu - we wnętrzach mieszkalnych kryteria tyczą się jednostki, a w użyteczności publicznej rezygnuje się z własnych oczekiwań na rzecz uniwersalności i dobra ogółu.

\section{Wybrane uwarunkowania projektowe}

Przeszklone ściany osłonowe są pełnowartościowymi przegrodami zewnętrznymi. Bardzo często ich stosowanie jest wynikiem długiego procesu projektowego, w którym łączy się funkcję budynku z kreacją jego zewnętrznej powłoki - formy architektonicznej. Bryła ma znaczący charakter w oddziaływaniu i interakcji $\mathrm{z}$ otoczeniem, a jej duże przeszklenia zapewniają zarówno otwarcia na otoczenie, jak i wykorzystanie naturalnego oświetlenia. Światło słoneczne jest głównym regulatorem rytmu człowieka. Ma znaczący wpływ na stymulację fotobiologiczną ludzi i w znaczącym stopniu odpowiada za formę psychofizyczną ludzi w ciąg roku. ${ }^{2}$ Warto zatem poznać problematykę stosowania tego typu rozwiązań i wpływu na środowisko wewnętrzne tworzone dla człowieka. Funkcje ścian zewnętrznych - w tym również ich przeszklonym partiom są doskonale znane, choćby te podawane przez Schitticha: ${ }^{3}$ zabezpieczenie przed uszkodzeniami mechanicznymi, wiatrem, wilgocią, ogniem, hałasem, przegrzaniem pomieszczeń i olśnieniem, ochrona cieplna, prywatności, ale również ich zadaniem są: naturalne nasłonecznienie, wentylowanie wnętrz, kontakt wizualny jak i pozyskiwanie energii w celu dogrzania pomieszczeń. Uniwersalność technologiczna i ogromny wachlarz możliwości adaptacji rozwiązań w zależności od indywidualnych potrzeb predestynuje stosowanie systemów przeszklonych ścian osłonowych do stosowania we wszystkich typach budynków - w tym także w obiektach mieszkalnych. Do niezaprzeczalnych zalet należą przede wszystkim względy estetyczne - transparentność, modularność, swoboda kształtowania oraz gabaryty poszczególnych elementów w połączeniu z dokładnością wymiarową i precyzją montażu. Prefabrykacja elementów minimalizuje możliwość występowania błędów montażowo-produkcyjnych przez wyeliminowanie wpływu czynnika ludzkiego w dużej części procesu powstawania. Pozwala również na osiąganie gwarantowanych, mierzalnych parametrów fizycznych, szczególnie energetycznych.

\footnotetext{
${ }^{2}$ Altomonte S.: Daylight and the occupant. Visual and Physio-psychological well-being in built environments. Plea2009 $-26^{\text {th }}$ Conference on Passive and Low Energy Quebec City, 2009

${ }^{3}$ Schittich Ch.: In Detail: Building Skins, Birkhäuser, Basel, Boston-Berlin 2006, s. 30
} 


\subsection{Stosowanie przeszklonych ścian jako elementów posiadających odporność ogniową}

Projektowanie architektoniczno-budowlane uwarunkowane jest przez akty prawne w celu zapewnienia ujednoliconych wymogów, m.in. opisującymi komfort i bezpieczeństwo ludzi, zwierząt i własności. Podstawowym rozporządzeniem regulującym zagadnienia projektowe na terenie Polski jest „Rozporzadzenie Ministra Infrastruktury $w$ sprawie warunków technicznych, jakim powinny odpowiadać budynki i ich usytuowanie. (Dz. U. Nr 75, poz. 690 z 2002 r. z późniejszymi zmianami)". Opisuje wymogi techniczne stawiane elementom budowlanym oraz kształtowaniu przestrzeni w zależności od projektowanej funkcji użytkowej. Opisuje również istotne kwestie zabezpieczenia pożarowego - zdecydowanie jednego ze składników komfortu w rozumieniu psychicznym.

W §216.1 czytamy, że budynki mieszkalne i zamieszkania zbiorowego w zależności od wysokości budynku muszą być wzniesione w klasach odporności pożarowej budynku [A] do [D] i zapewniać szczelność (E) i izolacyjność (I) ogniową od 30 do 120 minut . Z wymogu posiadania klasy odporności pożarowej są zwolnione budynki o trzech kondygnacjach włącznie - mieszkalne jednorodzinne, zagrodowe i rekreacji indywidualnej (\$213.1.a), mieszkalno-administracyjne w gospodarstwach leśnych (\$213.1.b) oraz wolnostojących o dwóch kondygnacjach włącznie o kubaturze brutto do $1500 \mathrm{~m}^{3}$ przeznaczonych do celów turystyki i wypoczynku (\$213.2.a), o kubaturze brutto do $1000 \mathrm{~m}^{3} \mathrm{z}$ częścią mieszkalną (\$213.2.c).

Analizując możliwości materiałów stosowanych w przeszklonych ścianach osłonowych można stwierdzić, że szkło klejone, ze względu na warstwy klejące i oddzielające, wykonane $\mathrm{z}$ tworzyw podatnych na wpływ temperatury, źle znosi zastosowania z zakresu ppoż. Producenci dysponują specjalnymi produktami posiadającym odpowiednie atesty do zastosowań ppoż. Szyby pożarowe dzielą się na ognioodporne oraz ogniochronne. Oba typy szyb zespolonych zapewniają ochronę przez promieniowaniem cieplnym (opisywane parametrem „E” klasy odporności pożarowej), a ognioodporne stanowią również barierę mechaniczną dla pożaru (opisywane parametrem „EI” klasy odporności pożarowej). ${ }^{4}$

Porównując dostępne na rynku systemy szklanych ścian osłonowych, można zidentyfikować potencjalne problemy stosowania ich jako przegród o odporności pożarowej. Metalowa konstrukcja nośna w większości przypadków wykonana jest $\mathrm{z}$ aluminium. Obecnie na rynku dostępne są rozwiązania słupoworyglowe legitymujące się atestem do stosowania całego systemu w parametrach pożarowych EI60. ${ }^{5}$ Zapewniają one szczelność i izolacyjność ogniową na poziomie 60 minut, natomiast nie zapewniają parametru nośności. We wspomnianym rozwiązaniu wewnętrzne przestrzenie słupów i rygli nośnych konstrukcji metalowej wyposażone są we wkładkę - wzmocnienie profilu wykonane z aluminium.

\footnotetext{
${ }^{4}$ Karta techniczna SGG PYROSWISS firmy Glaspol, 2008; Karta techniczna SGG CONTRAFLAM firmy Glaspol, 2008

${ }^{5}$ Karta techniczna producenta YAWAL System (45.E0 07/08)- Fasada 50 EI60
} 

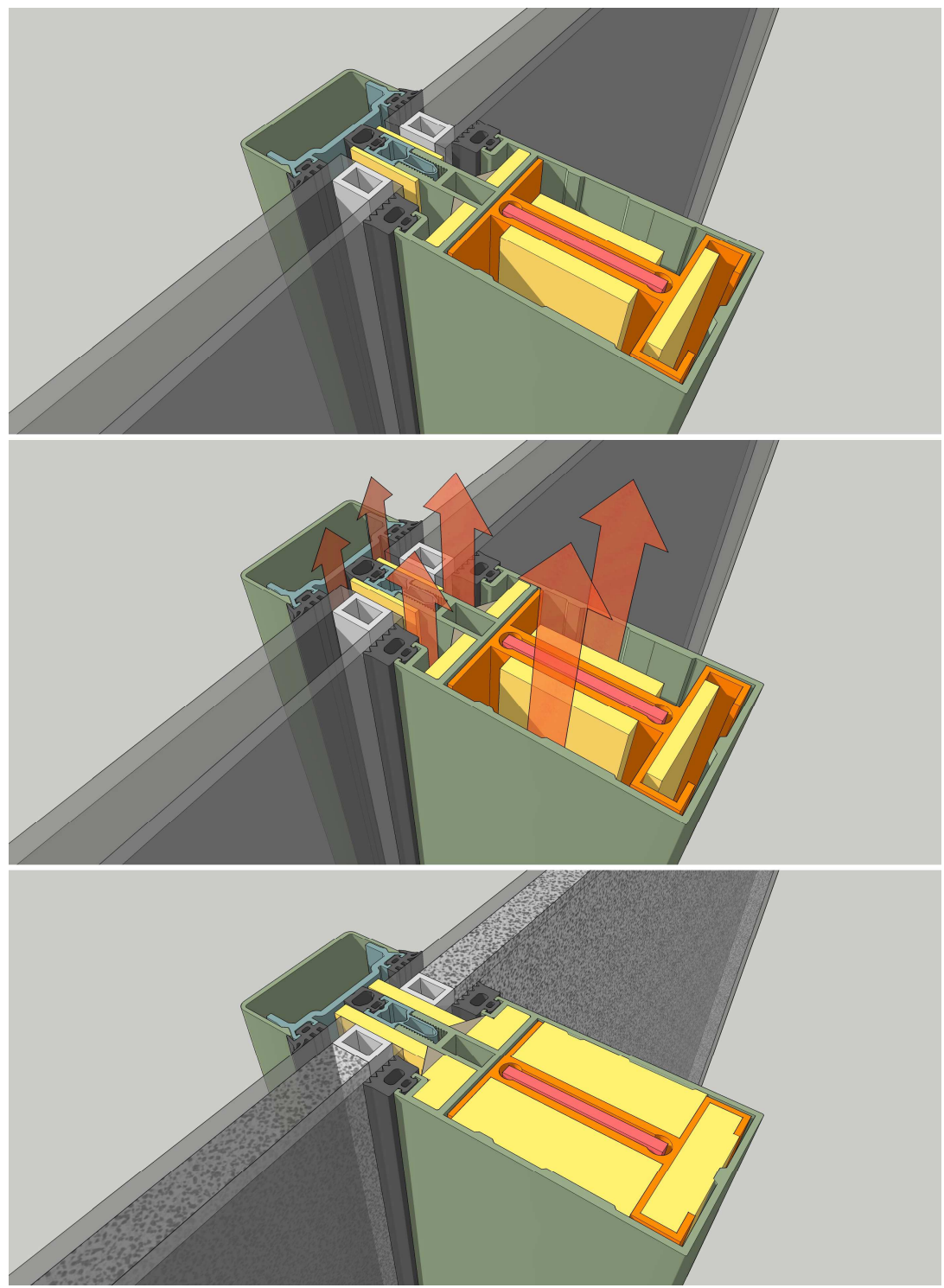

Rys. 1. Wzmocnienie konstrukcji oraz ochrona termiczna w systemach słupoworyglowych o odporności ogniowej - opracowanie własne

Fig. 1. Structure enhancement and thermal protection in fire protected pillar-beams construction systems - authors work

Zapewnia ona przeniesienie obciążeń i utrzymanie sztywności konstrukcji podczas utraty nośności profilu zewnętrznego przez określony czas. Profil zewnętrzny ma kształt skrzynkowy, profil wewnętrzny jest żebrowy - przestrzenie pomiędzy nimi wypełniane są taśmami uszczelniającymi wykonanymi z mate- 
riałów pęczniejących. Podczas bezpośredniego działania ognia lub pośredniego znaczącego wzrostu temperatury wewnątrz profilu nośnego, następuje spęcznienie materiału izolacyjnego. Zadaniem jego jest zabezpieczenie wewnętrznego profilu nośnego przed wzrostem temperatury poza nośność elementu chronionego. Dodatkowymi zabezpieczeniami jest wypełnienie przestrzeni dylatacyjnych oraz większych szczelin montażowych taśmami pęczniejącymi. Szczególnej ochronie i zabezpieczeniu z materiałem termo-rozszerzalnym poddane są słupy, rygle, listwy termiczne łączące listwę dociskową z profilem nośnym oraz węzły montażowe scalające konstrukcje metalową.

Dodatkowa ochrona pozwala na uzyskanie parametrów nośnych rzędu jednej godziny na najsłabszym ogniwie systemu. Szyby zespolone stosowane w przegrodach o klasyfikacji ogniowej musza pochodzić z asortymentu zapewniającego odpowiednie parametr. Producenci szkła atestują swoje produkty w klasach od E15 do EI 180, więc w obrębie całego systemu przeszklonych ścian osłonowych słupowo-ryglowych szczelność i izolacyjność ogniowa leży po stronie aluminiowej konstrukcji nośnej oraz po stronie elementów uszczelniających osadzenie szyby w metalowej konstrukcji. W przypadku zniszczenia lub przerwania elastycznych uszczelek na obwodzie zestawów szklanych dochodzi do przeniesienia gorących gazów, dymu i ognia do przestrzeni montażowych i do swobodnego rozgrzania konstrukcji ściany osłonowej w górę od miejsca penetracji. Następuje dalsza degradacja struktury ściany i dochodzi do przedostania się ognia i dymu do wyższych pomieszczeń. Podgrzane również zostaje powietrze uwięzione wewnątrz profili nośnych, następuje wzrost ciśnienia i osłabienie konstrukcji w partiach niezabezpieczonych pożarowo. Występowanie izolatorów pęczniejących pod wpływem temperatury we wnętrzu profili pozwala wytworzyć barierę dla swobodnego przepływu gorącego powietrza i ogranicza rozprzestrzenianie się pożaru i pogorszenie nośności w całej konstrukcji ściany osłonowej.

W zależności od typu budynku, klasyfikacji oraz jego wysokości koniecznym staje się wybranie odpowiedniego systemu szklenia. Aby spełnić podstawowe wymogi pożarowe koniecznym może być rezygnacja ze stosowania przeszklonych ścian osłonowych pełnoszklanych i mocowanych punktowo, gdyż obecnie nie posiadają odpowiednich dopuszczeń technicznych w omawianym zakresie. Jeżeli projektant jest zdeterminowany do utrzymania decyzji estetycznych jedyną drogą jest uzyskanie postanowienia Komendanta Wojewódzkiego Państwowej Straży Pożarnej umożliwiającego stosowanie indywidualnych rozwiązań ochrony pożarowej ze względu na brak możliwości zapewnienia wymogów podstawowych.

\subsection{Uwarunkowania energetyczne}

Ponieważ światło jest nośnikiem energii. Przy stosowaniu szklanych ścian osłonowych mamy do czynienia $\mathrm{z}$ transportem energii. W czasie ekspozycji słonecznej do wnętrza pomieszczeń przekazywana zostaje energia. Do zewnętrznej płaszczyzny fasady dociera w przybliżeniu $1,3 \mathrm{KW}$ energii na $1 \mathrm{~m}^{2}$ 
powierzchni. W zależności od charakterystyki fasady, znaczna część ciepła przenika do wnętrza, wobec czego bardzo łatwo jest doprowadzić do przegrzania pomieszczenia przez przeszklenia o znacznej powierzchni. ${ }^{6}$

Posadzki oraz ściany pomieszczenia, która zostaje oświetlona światłem słonecznym, zostają podgrzane. Zdolności akumulacyjne przegród mają wpływ na charakterystykę temperaturową środowiska wewnętrznego w układzie dobowym. Struktury pozyskujące energię w ciągu dnia stopniowo wypromieniowują ciepło do wnętrza, zapewniając dalsze uzyski ciepła. Akumulacyjność zależy od grubości warstw wierzchnich, ich materiału oraz sposobu montażu. Elementy cięższe o litej strukturze zapewnią większe zyski niż materiały porowate, lekkie o strukturze ażurowej. Układy o warstwach klejonych powierzchniowo zapewnią efektywniejsze kumulowanie energii z warstwami niższymi, niż te separowane warstwami niespajanymi. Pojemność cieplna okładzin ma decydujący wpływ na temperaturę wewnętrzną i jest trudno sterowalna ze względu na dużą bezwładność tego zjawiska.

Badania wskazują, że rozwiązania pasywne zapewniające ograniczenie możliwości przenikania do wnętrza promieni słonecznych są najkorzystniejszym ekonomicznie rozwiązaniem zapewniający przewidywalny rozkład temperatur we wnętrzach mieszkalnych. Analizy orientacji budynku względem stron świata, wielkości przeszkleń i ich ekspozycji, dobór powłok refleksyjnych i żaluzji słonecznych zapewnią oszczędności na energii potrzebnej do nadprogramowej wentylacji i chłodzenia pomieszczeń.

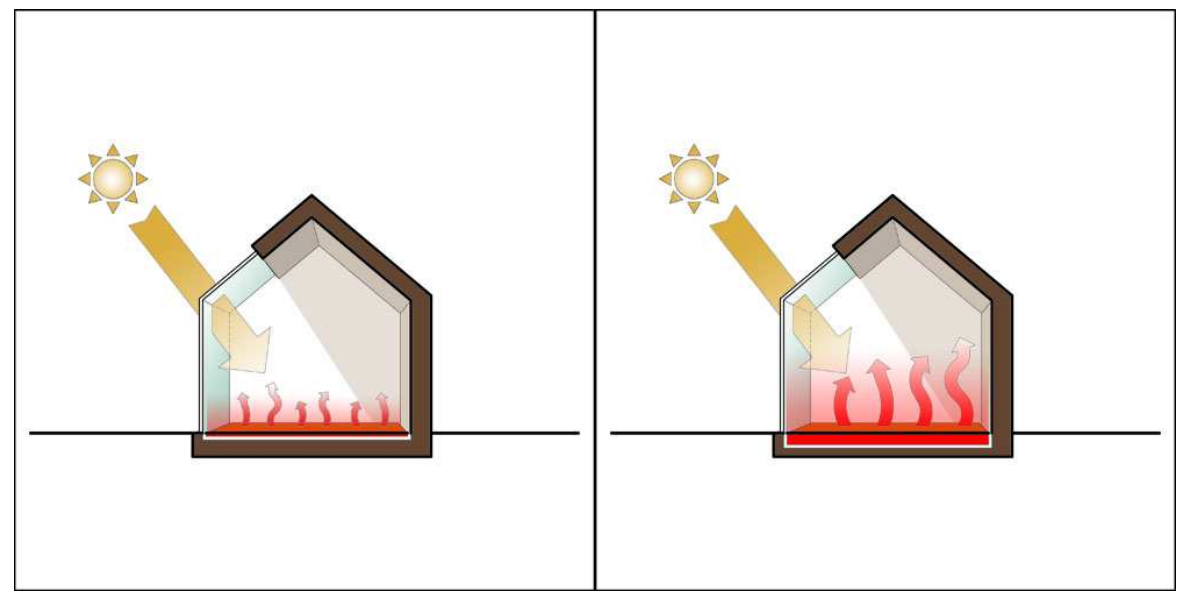

Rys. 2. Akumulacyjność cieplna powierzchni oświetlanych słońcem - opracowanie własne

Fig. 2. Heat accumulation of the surfaces illuminated by the sun - authors work

\footnotetext{
${ }^{6}$ Nowak Ł., Nowak H.: Wptyw wybranych charakterystyk przegrody przeszklonej na bilans cieplny pomieszczenia biurowego. Energia i Budynek 11/2009, s. 23

${ }^{7}$ Kisilewicz T.: O racjonalnym kształtowaniu niektórych elementów obudowy zewnętrznej budynków niskoenergetycznych, Wystąpienie na konferencji X NBTAD 2013, Kraków
} 
Doprowadzenie do przegrzania pomieszczeń skutkowało będzie długotrwałym utrzymywaniem się podwyższonej temperatury powietrza, większą wilgotności jak i zwiększonym poceniem się użytkowników. Częstsza będzie zatem konieczność wymiany powietrza, możliwa do zapewnienia wyłącznie przez sprawną wentylację mechaniczną nawiewno-wywiewną. Stosując odpowiednią automatykę i zestaw wielozakresowych czujników możliwe jest szybkie i skuteczne reagowanie na zmieniające się warunki cieplno-wilgotnościowe wewnątrz budynków mieszkalnych.

Pomijając kwestie zasilania urządzeń infrastruktury grzewczej, chłodzącej i wentylującej możliwe jest utrzymywanie parametrów jakościowych środowiska wewnętrznego na realnie stałym, zadanym poziomie. Należy tutaj również wspomnieć o syndromie chorego budynku (SBS - Sick Building Syndrome). Uznaje się, że przebywanie człowieka w całkowicie sztucznym środowisku, gdzie parametry jakościowe przestrzeni znajdują się na stałym poziomie, jest głównym czynnikiem wywoływania syndromu. Granicą określającą występowanie zespołu jest poziom 30\% stałych użytkowników budynku nieusatysfakcjonowanych warunkami środowiska wnętrza. ${ }^{8}$ Zmienność bodźców środowiskowych, pomimo jej sprzeczności ze stałym pojęciem warunków komfortu, ma jednak korzystny wpływ dla organizmu poprzez ciągłą konieczność przeprowadzania procesów adaptacyjnych. ${ }^{9}$ Komfort zatem należy rozpatrywać w ujęciu wycinkowym, chwilowym, czy może jest funkcją rozłożoną w czasie?

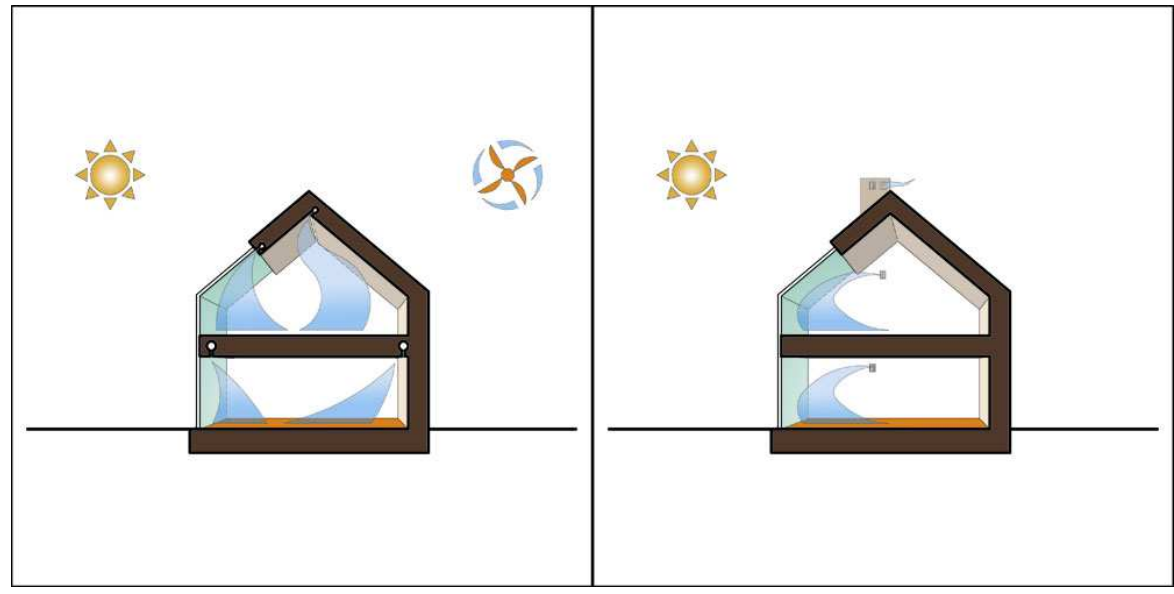

Rys. 3. Wydajność i sterowalność wentylacji mechanicznej w porównaniu do wentylacji grawitacyjnej - opracowanie własne

Fig. 3. Efficiency and controllability of mechanical ventilation comparing to natural ventilation - authors work

${ }^{8}$ Sowa J.: Kształtowanie założonego poziomu jakości środowiska $\mathrm{w}$ budynkach biurowych: Budynek Inteligentny, Wydawnictwo Politechniki Śląskiej, Gliwice 2010, s. 154

9 Kuczia P.: Architektura pomiędzy „Sun block” i „summer look”. Materiały V Sympozjum „Architektura i Technika a Zdrowie”, Wydawnictwo Politechniki Śląskiej 2007, s. 167 
Wydaje się, że komfort jest pojęciem psychologicznym, a zdrowotny aspekt środowiska wewnętrznego ma ścisłe pojęcie z fizycznymi parametrami. Często oba te pojęcia stoją w opozycji. Odczuwanie komfortu termicznego jest wrażeniem subiektywnym dla każdego człowieka. Zależy on od indywidualnych predyspozycji i bodźców obserwatora w danej chwili. Uśredniając jednak komfort, można opisać jako warunki obojętne odczuwane w otoczeniu. ${ }^{10}$ Technologia powinna w aktywny sposób reagować na zmiany zachodzące po obu stronach fasady. Zmiany mogą mieć charakter cykliczny - np. zmiany dobowe w oparciu o ekspozycję słoneczną, zmiany okresowe - np. zwiększenie ilości użytkowników. Po zmierzchu powierzchnia szklana działa na niekorzyść warunków energetycznych, pozwalając na kontrolowaną ucieczkę ciepła z wnętrza na zewnątrz przegrody. Kierunek przepływu energii jest przeciwny, natomiast straty jednostkowe są niewielkie ze względu na brak silnego źródła wypromieniowywania energii - główne straty występują na powierzchni powietrze-szkło i są drobne lecz długotrwałe. Wychłodzenie okolicy szyb, szczególnie widoczne nocami oraz w okresach zimowych, jest źródłem wzmożonej konwekcji i szczególnie w dużych pomieszczeniach może powodować lokalne przeciągi. ${ }^{11}$ $\mathrm{W}$ celu ograniczenia tych strat stosuje się rozwiązania ograniczające radiację ciepła - powłoki niskoemisyjne, ruchome żaluzje wewnętrzne czy rolety zewnętrzne. Zjawisko wytworzenia dodatkowej komory przy szkleniu, pomimo braku jej szczelności ogranicza zasięg i siłę ucieczki ciepła poprzez ograniczenie przestrzeni ośrodka sąsiadującego z powierzchnią szyby. Zaleca się również wykorzystanie w bilansie dobowym możliwości ochładzania przegrzanych wnętrz przy pomocy nieosłanianych przeszkleń, zwłaszcza lokalizowanych po stronie północnej.

Analizując problematykę oświetlania i nagrzewania wnętrz przez duże powierzchnie przeszkleń należy wspomnieć o podwójnych fasadach. Układ ściany osłonowej w formie podwójnej fasady posiada kilka dodatkowych zalet i jest następnym krokiem rozwoju przegród szklanych. Pozwala na zdwojenie warstw termoizolacyjnych, wytwarza dodatkową przestrzeń buforową dla rozkładu temperatur, zysków i strat ciepła oraz hałasu. Pozwala na zróżnicowanie estetyki ścian w warstwie zewnętrznej i wewnętrznej (choćby na odwrócenie układu konstrukcyjnego tak, aby znajdował się po wewnętrznej stronie przestrzeni międzyściennej). Umożliwia również zastosowanie adaptacyjnych hybrydowych systemów wentylacji ${ }^{12}$ łączących zalety wentylacji grawitacyjnej (zwłaszcza wspomaganej solarnie - tzw. Kominy słoneczne) i wentylacji mechanicznej.

\footnotetext{
${ }^{10}$ Lis A.: Wielkość powierzchni przeszklonych a wskaźniki komfortu cieplnego ludzi. Energia i Budynek, 12/2009, s. 16

${ }^{11}$ Ibidiem s. 20

${ }^{12}$ Brzezicki M.: Podwójne fasady - zdrowe budynki, Materiaty II Sympozjum „Architektura i Technika a Zdrowie” Wydawnictwo Politechniki Śląskiej, Gliwice 2004, s. 35
} 


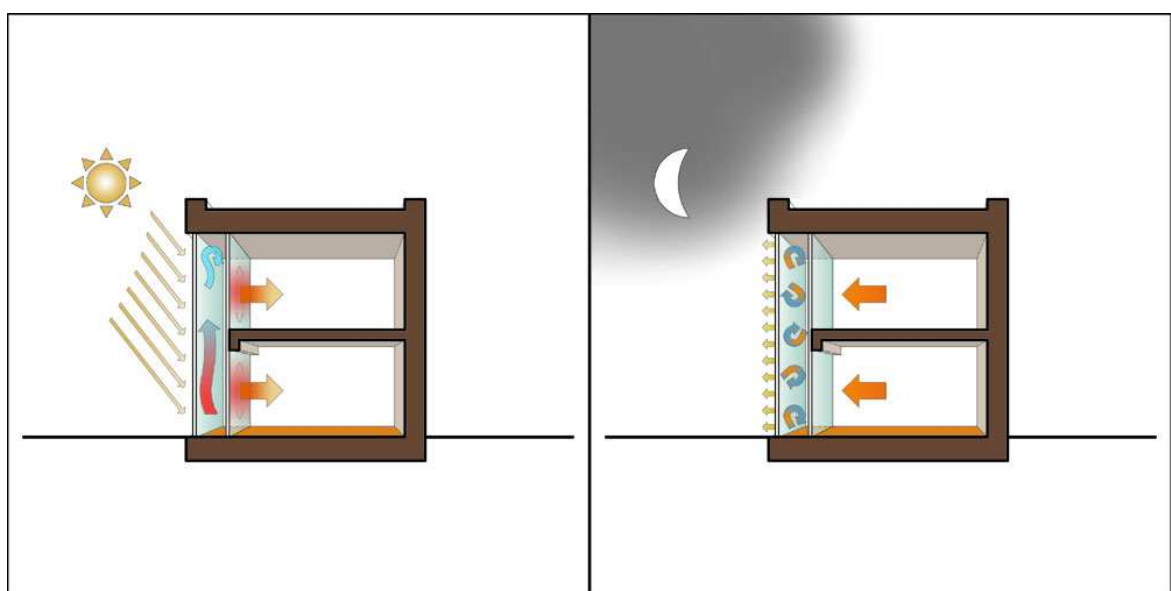

Rys. 4. Rola układu podwójnej fasady w dobowym rozkładzie temperatur-opracowanie własne

Fig. 4. The role of the double skin facade in the daily distribution of temperature - authors work

Takie rozwiązanie pozwala w zależności od warunków i pory roku stosować bardziej wydajny system wentylacji, ograniczając zużycie prądu i wprowadzając dywersyfikację dostaw powietrza.

\subsection{Prywatność przestrzeni ograniczonych przeszklonymi ścianami osłonowymi}

Współczesne tendencje w kształtowaniu architektury mieszkaniowej zwracają się w stronę eliminowania ilości elementów składowych przegród i maksymalizacji powierzchni przeziernych $\mathrm{w}$ ścianach osłonowych. Technologicznie możliwe jest uzyskanie parametrów przegrody zarówno mechanicznych, jak i energetycznych, wobec czego projektanci coraz chętniej wykorzystują możliwość wizualnego łączenia zewnętrza z przestrzeniami wewnętrznymi. Należy zwrócić uwagę, iż swobodne przenikanie światła w obu kierunkach przegrody niesie za sobą pewne niebezpieczeństwa, zwłaszcza przy stosowaniu tego typu rozwiązań w układach ze wspólną przestrzenią półprywatną (osiedla, domy wielorodzinne, budynki czasowego zamieszkania). Jak wiadomo kierunek przenikania światła odbywa się swobodnie w kierunku ośrodka o niższym natężeniu światła, wobec czego granicznym okresem zmiany kierunku przezierności przegrody, zwłaszcza z powierzchnią refleksyjną, jest pora zapadania zmierzchu i pora świtu. Z reguły ważną wytyczną przy projektowaniu szklanej ściany osłonowej jest możliwość aktywnego sterowania przeziernością lub zastosowanie rozwiązań pasywnych. Jednym z dostępnych rozwiązań umożliwiających sterowanie własnościami optycznymi przeszklenia są żaluzje zewnętrzne, ruchome rolety lub blendy. Ich rolą jest mechaniczne zmniejszenie stopnia transmisji światła (przezierności) przez zasłonięcie części obrazu. Przydatne jest 
również przy ograniczeniu olśnienia światłem dziennym, którego jasność może wynosić nawet 5000 lx. ${ }^{13}$ Ze względu na zmienny charakter nasłonecznienia przestawność jest ważna dla uzyskania optymalnych efektów zacieniania płaszczyzny szkła. Sterowanie może odbywać się automatycznie lub ręcznie. ${ }^{14}$ Rolety z możliwością szczelnego zamknięcia mogą poprawić bilans strat ciepła przez powierzchnię okna.

Innym rozwiązaniem pozwalającym zdalnie zmieniać właściwości optyczne oszklenia są zintegrowane powłoki ciekłokrystaliczne lub pizoelektryczne. Warstwa aktywna reaguje na zmiany napięci elektrycznego przyłożonego do styków. Przepływ prądu polaryzuje cząstki zapewniając całkowitą przejrzystość przegrody. Odłączenie zasilania umożliwia natychmiastowy powrót do chaotycznego układu cząstek. Sytuacja tak powoduje powstawanie załamań światła i znaczące ograniczenie przejrzystości optycznej przegrody. Nadal możliwy jest jednak transport blasku przez przegrodę. Nie bez znaczenia pozostają również dodatkowe walory estetyczne, pozwalające podnieść prestiż i odbiór budynku, w którym zastosowano rozwiązania aktywne, ze względu na jego zmienność w czasie.

Pośród rozwiązań zmiennych można przywołać również stosowanie warstw termotorpowych (zmieniających się pod wpływem temperatury - np. ciepła ciała ludzkiego i reakcji na dotyk) fototropowych (reagujących na ilość światła) lub np. reagujących na zmiany ciśnienia.

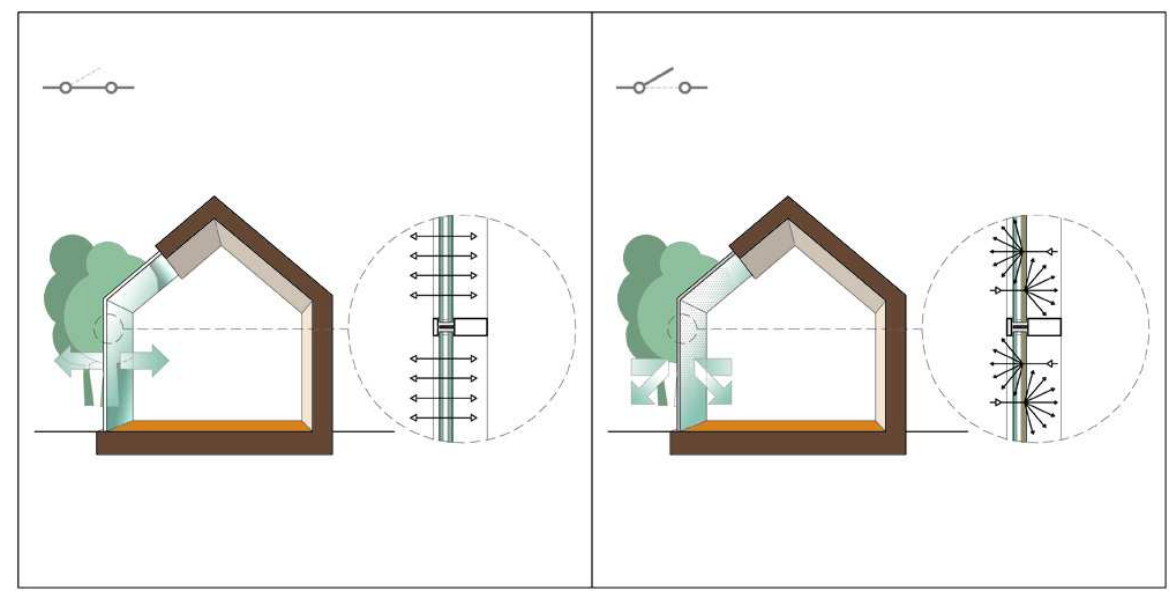

Rys. 5. Elektryczne sterowanie przeziernością oszklenia w ścianie osłonowej - opracowanie własne

Fig. 5. Electric contorlled translucency in the curtain wall glazing - authors work

${ }^{13}$ Złowodzki M.: O środowisku architektonicznym pracy biurowej. Wydawnictwo Politechniki Krakowskiej, Kraków 1992, s. 210

${ }^{14}$ Żurawski J.: Ostony przeciwstoneczne cz. I. Energia i budynek 03/2010, s. 28 


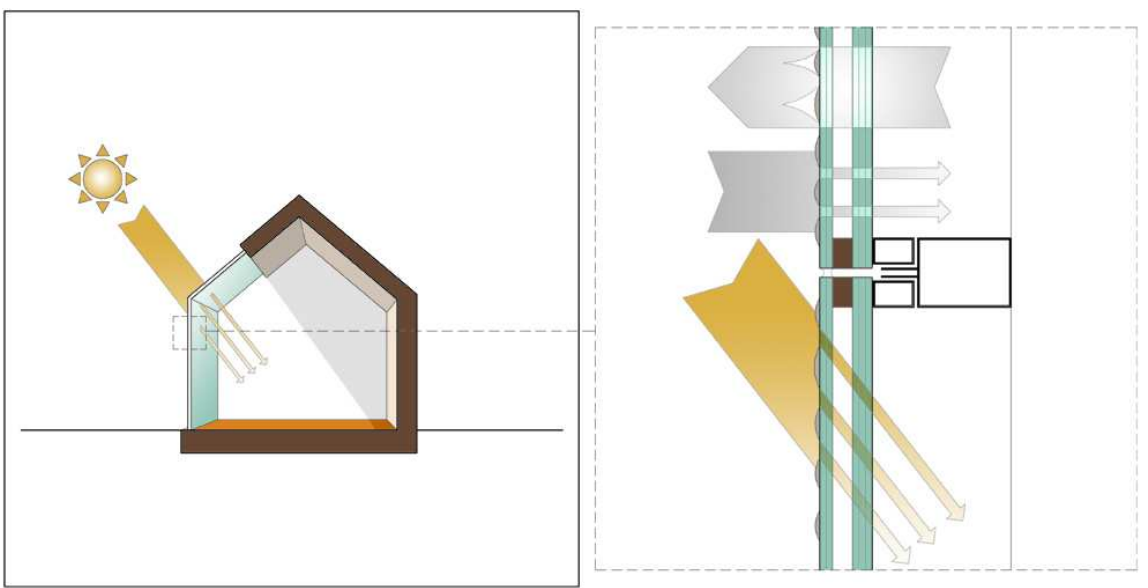

Rys. 6. Nadruk na powierzchni szkła - opracowanie własne

Fig. 6. Printing on a glass surface - authors work

Odmienne podejście do kwestii wglądu przez przegrodę przeszkloną prezentują rozwiązania stosujące nadruk na powierzchni szyb. Technologia bierna umożliwia wprowadzenie stałego stopnia ograniczenia transmisji światła poprzez naniesienie sitodruku. Nieprzejrzyste krople farby ograniczają powierzchnie przejrzystą szkła. Dodatkowym walorem tego rozwiązania jest możliwość stosowania tego typu rozwiązań jako antypoślizgowości tafli szklanych przy aplikacjach poziomych.

\section{Wnioski i perspektywy rozwoju}

Możliwości konstrukcyjne wznoszenia przeszklonych ścian osłonowych zbliżyły się do granic rozwoju. Systemy szklenia bezramowego pozwalają przy zachowaniu dużej transparentności przekrywać duże powierzchnie. Jest to pole do dalszej ewolucji, natomiast już obecnie możliwe jest wznoszenie form architektonicznych bazujących na wrażeniu dematerializacji części budynku. Transparentność obiektów architektonicznych świadczy o ich nowoczesności. Nowe technologie będą wpływać na rozwój estetyczny przeszklonych fasad, natomiast dziedziną podlegającą ekspansywnemu rozwojowi staną się badania i rozwiązania techniczne wykorzystujące szkło jako sztywny nośnik kształtu. Integrowanie warstw w szybach zespolonych pozwoli wykorzystywać produkty szklane jako efektywne termoizolacje, bariery wizualne, fasady aktywne multimedialnie oraz dwuwarstwowe struktury adaptujące wymagania środowiskowe wnętrz do warunków zmiennych. Przestrzeń buforowa będzie magazynem energii, śluzą dla zanieczyszczeń i hałasu oraz barierą pożarową. Aktywne warstwy wmontowane pomiędzy szyby odpowiadać będą za produkcję $e^{15}$ i dystrybucję energii na

${ }^{15}$ Pietruszko S.M.: Systemy fotowoltaiczne (cz. 1). Energia i Budynek 03/2010, s. 22 
potrzeby budynku, będą reagować na wymagania natężenia oświetlenia, temperatury i przezierności. Solarna aktywacja fasad umożliwi wykorzystanie przestrzeni płaskich do regulowania bilansu cieplnego budynków ${ }^{16}$ i będzie umożliwiała uzyskanie samowystarczalności budynku. Przeszklone ściany osłonowe nie posiadają przeciwwskazań do stosowania ich w budownictwie mieszkaniowym. Adaptacja rozwiązań technicznych przebiega w sposób zadowalający, i coraz więcej dużych przeszkleń montowanych jest w realizacjach domów i apartamentowców. Należy podkreślić konieczność szerokiego spojrzenia na problem projektowania szklanych fasad w architekturze mieszkalnej. Znalezienie odpowiednich proporcji pomiędzy doświetleniem a przegrzaniem pomieszczeń, przeziernością ściany osłonowej a wychładzaniem pomieszczeń, problemami akustyki, bezpieczeństwa pożarowego, wentylowania wnętrz i proporcji przeszkleń wymaga wielobranżowej współpracy już na etapie projektowania. Wstępny dobór rozwiązań zależy od układu funkcjonalnego i gabarytu budynku - przewidywanej kubatury i ilości kondygnacji. Złożoność problematyki związanej z utrzymaniem względnie stałego środowiska wewnętrznego sprawia, że projektuje się właściwie system dystrybucji i dozowania energii cieplnej i świetlnej do wnętrza pomieszczeń mieszkalnych w czasookresach dobowych, tygodniowych czy kwartalnych. Wszystkie decyzje o podłożu estetycznym, niepoprzedzone konsultacjami i parametryzowaniem przestrzeni przesłanianej szkleniem, wydają się być skazane na niepowodzenie pod kątem uzyskania komfortu środowiskowego we wnętrzu pomieszczeń mieszkalnych.

\section{Literatura}

[1] Altomonte S.: Daylight and the occupant. Visual and Physio-psychological well-being in built environments. Plea2009 - 26 ${ }^{\text {th }}$ Conference on Passive and Low Energy Quebec City, 2009.

[2] Behling S.: Fuchs A., Peters S.: Transparente Experimente - Projekte aus Forschung und Entwicklung, Detail nr. 7/8, 2009, Munchen 2009, s. 762-774.

[3] Brzezicki M.: Podwójne fasady - zdrowe budynki, Materiały II Sympozjum „Architektura i Technika a Zdrowie" Wydawnictwo Politechniki Śląskiej, Gliwice 2004, s. 35.

[4] Kuczia P.: Architektura pomiędzy „Sun block” i „,summer look”. Materiały V Sympozjum „Architektura i Technika a Zdrowie”, Wydawnictwo Politechniki Śląskiej 2007, s. 167.

[5] Lis A.: Wielkość powierzchni przeszklonych a wskaźniki komfortu cieplnego ludzi. Energia i Budynek, 12/2009, s. 16.

[6] Loughran P.: Falling glass: problems and solutions in contemporary architecture, Wyd. Birkhauser, Basel 2003.

[7] Michałowski T.: Szkło o zmiennej przezierności, Świat Szkła 4/2013.

[8] Molter P.: Techniques for Bending Glass, w: Detail nr. 1+2/2011, s. 80-86.

[9] Nowak Ł.: Nowak H.: Wpływ wybranych charakterystyk przegrody przeszklonej na bilans cieplny pomieszczenia biurowego. Energia i Budynek 11/2009, s. 23.

\footnotetext{
${ }^{16}$ Behling S., Fuchs A., Volz T.: Solare Architektur - Forschung und Entwicklung, Detail 6/2007, s. $666-669$
} 
[10] Pietruszko S.M.: Systemy fotowoltaiczne (cz. 1). Energia i Budynek 03/2010, s. 22.

[11] Przewodnika po Szkle SAINT-GOBAIN GLASS, 2009.

[12] Schittich Ch.: In Detail: Building Skins, Birkhäuser, Basel, Boston-Berlin 2006, s. 30.

[13] Sowa J.: Kształtowanie założonego poziomu jakości środowiska w budynkach biurowych: Budynek Inteligentny, Wydawnictwo Politechniki Śląskiej, Gliwice 2010, s. 154.

[14] Tymkiewicz J.: Funkcje ścian zewnętrznych w aspektach badań jakościowych. Wpływ rozwiązań architektonicznych elewacji na kształtowanie jakości budynku, Monografia, Wydawnictwo Politechniki Śląskiej, Gliwice 2012.

[15] YAWAL, Karta techniczna producenta System (45.E0 07/08)- Fasada 50 EI60.

[16] Złowodzki M.: O środowisku architektonicznym pracy biurowej. Wydawnictwo Politechniki Krakowskiej, Kraków 1992, s. 210.

[17] Żurawski J.: Osłony przeciwsłoneczne cz. I. Energia i budynek 03/2010, s. 28.

\section{IMPACT OF GLAZED CURTAIN WALLS ON COMFORT IN RESIDENTIAL INDOOR ENVIRONMENT - SELECTED ASPECTS}

\section{S u m m a r y}

The use of glass curtain walls in residential buildings is more frequent practice. These solutions have many advantages - especially aesthetic - but the wrong application expose many problems in use and provides to strong influence on the quality of the internal environment. Few aspects of use of large glazing are listed and discussed in terms of impact on residential indoor comfort . Paper uses analogies and comparisons to recognized phenomenons occurring in other types of buildings and analyzed them taking into account the specificities of housing. The work attempts to determine the components of the internal environment comfortable living spaces, presenting it in terms of measurable and immeasurable. In an analysis of the factors author takes into account the impact of psychological and physical and social context of raised issues. Among the aspects of the application of the partitions paper discusses issues related to fire safety, energy issues and the translucency of glass surfaces. The article describes the technology of construction and specific technical solutions that take advantage of large glazed areas and ensuring limiting adverse effects on indoor environmental quality. Another goal of this work is also to draw attention to the need for a broad perspective on the issues of the use of this type of curtain walls, especially in residential buildings. The complexity of conditions and a wide range of mutual interaction, increases the complexity of the technical documentation forcing the interdisciplinary consultation at an early stage of design. The author attempts to describe the solutions and determine the suitability of fields of application basing on the various design guidelines.

Keywords: fire safety of glazing, heat accumulation, the privacy of the glass partitions, gains and losses of heat through the glazing

Przestano do redakcji: $28.10 .2015 \mathrm{r}$.

Przyjęto do druku: 30.10 .2015 r.

DOI:10.7862/rb.2015.133 